\title{
THE KING'S PARDON: A GENRE IN DOCUMENTARY TYPOLOGY (MONTPELLIER-PERPIGNAN- BARCELONA, 1274)
}

Robert I. Burns, S.J.

The registers of King Jaime or Jaume the Conqueror preserve copies of some ten to fifteen thousand documents issued by his chancery during the last twenty years (1257-1276) of his long reign. They represent only a selection from the mass of charters which traveled out over his many realms and jurisdictions, there to disappear eventually, leaving behind these official and legal mirrors as paper originals of the lost parchments. One type which recurs insistently in the register codices is the royal padron. Neglected, almost ignored in the study of these realms, the pardon is not only an important source for legal history but also a fascinating trove of details for social history ${ }^{1}$.

An explanation of the royal pardon was incorporated into the

1 On the registers, their home in Barcelona's Arxiu de la Corona d'Aragó (the ACA below), and related context see my Society and Documentation in the Crusader Kingdom of Valencia (Princeton University Press: in press). On documentary typology - notarial, archival, and historical- see chapter 21; see also my «Los límites interiores de la Valencia de la Reconquista: un género de tipologia documental», Medievalia I, Barcelona 1980, pp. 9-34. 
literary closet-code of Roman law called the Siete partidas, devised by King Jaume's contemporary and son-in-law King Alfon: so the Learned of Castile and Revised by subsequent hands. It devotes one chapter or title to the drafting of such pardons and another to the pardon itself - its nature, kinds, author, recipient, reasons, timing, and effects. A proper pardon was an indult or privilege, rather than an amnesty from both criminality and punishment. It did not release the culprit from answering in civil law to the offended or complaining parties, but rather released him from criminal prosecution. If conferred before sentencing, it released the recipient from liability to punishment, and restored him to his previous property and standing in the community, though it could not guarantee his good reputation in full. If conferred after sentencing, it released him from punishment; only if the charter explicitly so ordered did he then recover property, reputation, and status.

A pardon could come at the request of some important person (as a «grace» or gift), or from compassion («pity»), or from gratitude for service by the culprit or his family (a «mercy»). More practically it might express in Roman-Law mode the custom-law termination of feuds or public disturbance. Alfonso the Learned tells us that only a sovereign could issue one, and that it must be a formal and duly sealed charter. In Jaume's realms at this time, particularly in the Catalan heartland, in southern France, and in the Valencian conquest, Roman Law was daily intensifying its influence both at the king's court and at the more resistant grass-roots level. The pardon was prime expression of that renaissance of Law, and a prerogative which both strengthen the ruler's Roman Law sovereignty and echoed the customary past ${ }^{2}$.

As a legal phenomenon, the king's pardon in the realms of Aragon invites scholarly study: searching out the scattered but abundant cases, analyzing their formulas and content, compiling

${ }^{2}$ Alfonso X, Las siete partidas, 3 vols. Madrid [1807] 1972, part. III, tit. 18, ley 12; part III, tit. 32. On the legal reanaissance in Jaume's realms see my «El dret canònic i la Reconquesta: convergència i simbiosi », in my Jaume I $i$ els valencians del segle XIII, Valencia 1981, ch. II. 
statistics, and organizing the resultant data. As to their content, we need to know what classes or kinds of people received them and in what proportion, what crimes were represented and in what percentage, how frequently and at what rate they appeared throughout a given reign. While the historian of law or archivistics pursues that course, however, the historian of society will have a different agenda. The king's pardon must take its place in the documentary typology for social history. These episodes are a window on the general society and on critical moments for individuals of all ranks or for families and communities. Sometimes the episodes preserve mundane details of living that are not otherwise accessible. Their peculiar nature as crime-oriented requires caution in analyzing or generalizing; but every documentary type must develop its own rules for interpretation.

The cases given here 1 took at random during this past summer in the Archives of the Crown of Aragon. A single codex was selected, number nineteen, and a ten-month period from a single year within it. The time-span was March into December, 1274. Some twenty pardons appeared, among a total of some two hundred charters, an incidence of nearly ten per cent. Documents from that same year and those same months also appear in at least six other volumes of Jaume's nearly thirty registercodices $^{3}$. Our percentage is valid only for this register therefore, and must be tested eventually against a wider sampling. Register nineteen seems a representative codex, however, so that the incidence of pardons suggests that they formed an important element in the king's rule and a unifying factor in governance of the realms. All cases during these months involved King

${ }^{3} \mathrm{ACA}$, Cancilleria, regs. 16, 17, 18, 20, 22 and 23; see also regs. 28, 33, 35, 37 of Jaume I, but from the Infant Pere. Ambrosio Huici's Colección diplomática de Jaime I, el Conquistador (3 vols. as 6, Valencia 1916-1922) had gathered all published versions of the king's output; for 1274 he gives four pardons, of which three concern the Jew Astrug and come from our register nineteen (March 19-23), and one as below in note 8 from register twenty. The amplified revision of Huici by M.D. Cabanes Pecourt, Documentos de Jaime I de Aragón (4 vols. to date, Valencia 1976 ff.), has not reached 1274. 
Jaume's Catalan or southern French towns, not Aragonese or Valencian or Balearic places. This localization doubtless relates to the king's own movements during the ten months, as he made his ceremonial way up the length of Catalonia and the Occitan coast to the ecumenical Council in Lyons at the head of the Rhone River, and then back again to Barcelona4. Cases from other regions probably awaited his regular tours and personal presence there. One small advantage to handling a run of charters so concentrated geographically, is that the Catalan or Occitan names of persons are more surely identified and translated from their Latin forms. The circumstance also recommends our using the king's Catalan name form, Jaume.

The twenty cases from which the five below have been selected involve kidnaping, rape, assault, false witness, wounding, brawls, larger riots, a quarrel between nobles, a Jew's lese majesty and his suicide, some killings, export of prohibited merchandise, and a debt (only one case, surprisingly). The few cases permitted here by the space available for this article run from June 13 to August 15 . Our first document, given at Perpignan on June 17, concerns «the death" of Berenguer de Manresa (Minoris$s a$ ), and the suspicion which had consequently fallen on Berenguer de Na Flors, himself now deceased. A group of ten petitioners from the Perpignan region -including a cleric, a Knight Hospitaller, and one woman - seem to be the heirs of Na Flors. Since Na Flors «was accused» of Manresa's death, they want their titles cleared now on the «lands, buildings, vineyards, and other possesions» of Na Flors. The king therefore «absolves and remits» them all from any legal liability arising from Manresa's death, and restores clear title to them for these properties. The ten, who do not seem to have been accomplices, are: Tomàs Fabre, Bernat Antoni cleric, Arnau Poch, Guillem Guaita, the woman Astruga Arrufat, Bernat Domènec, Eldiard Galli or Gallin, Bernat de Bayoles, «the Hospitaller brother Guerau de Salses» in Roussillon, and Ermengot the son of the deceased Joan Pagès.

4 An outline and details of the king's activity and itinerary that year is in Joaquim Miret i Sans, Itinerari de Jaume I «el Conqueridon (Barcelona 1918), pp. 491-511 and table on p. 566. 
The focus remains on property, and does not affect or even judge the guilt of the culprit himself. This document expands our concept of the king's pardon, in effect restoring the accused's property-title posthumously and bringing order to a complicated property situation 5 .

The second case, on June 26 and also at Perpignan, reassumes two women who had fled Montpellier under suspicion as accomplices in the death of a Joan de Freixe - Guillemeta and her mother Guillema. The crown's investigation had concluded that the two «were not guilty». Anyway, the main culprits themselves had already arranged monetary compensation or settlement with the dead man's relatives, so that they were now able to go around freely in Montpellier. The king therefore «absolves» the women from all «civil and criminal penalties», in person or property, which public authority might visit on them. He expressly allows that «you may return and reside in Montpellier, safe and secure and without fear of any punishment, under our safeguard and protection»). The safeguard was the usual guidaticum (Catalan guiatge), which involved fines and royal displeasure on those who defied it. It is hard to say whether the women were truly innocent in this case, or merely given their freedom because the case against the principals had collapsed. Their criminal agreement (consentire) may only have been acquiescence of a passive sort. «Those who perpetrated that death" were themselves walking abroad, free and forgiven by the family. Private custom apparently had forestalled action by public authority here, with the king now acquiescing in the state of calm. Again the crown was validating post hoc a settled situation - not our usual idea of a pardon ${ }^{6}$.

${ }^{5}$ ACA, Jaume I, Reg. Canc. 19, fol. 133 (13 June 1274) in appendix below, doc. I. The term inculpatus here yields its Classical sense of «innocent» to the medieval «accused". The surname Arrufad(e) may perhaps read Arustud. A Berenguer de Manresa from Cervera had received the king's pardon in 1257 after kidnaping the daughter of Guillem dÒdena and delivering her to Guillem d'Aguiló; but the name may well be a coincidence (Miret, Itinerari, p. 263.

${ }^{6}$ Reg. 19, fol. 139v (26 June 1274) in appendix below, doc. II. In translating the names, variants for the two women might be Guilleuma and Guilleumota. Pena here is not abbreviated persona. 
A third situation was much more complex, involving both sexual scandal and malfeasance by public authority. There are two stories here. A notary of Perpignan, Bernat Querol, had been charged with suborning a witness: «he counseled Guillema Mola of Tellosa to bring Guillem Sancho into court as witness, that he might bear false testimony for her in the matter of the marriage of this Guillema and Guillem of Vallespir». The crown later called witnesses concerning the charge, and found the three guilty. Roman Law, as reflected in the academic code of Alfonso the Learned, prescribed cutting off the hand of any notary who had falsified his document. It also imposed einfamy» upon him, so that he could never be a notary or even a witness again, «or be honored while he lives". Ordinary false witness by anyone «deserves severe punishment»; but because circumstances can differ, actual penalties were left to the discretion of the judge. Other contemporary codes, such as King Jaume's Furs fo the Valencian kingdom, also define and apply infamy - as arising from murder, rape, «and any similar crime».

Guillema confessed to her own role, and her witness Guillem Sancho admitted both his perjury and the woman's instigation. This was only the beginning of our notary's troubles. He had also charged Bartomeu de Mans, lieutenant of the crown bailiff for Perpignan, with kidnap or rape of the notary's wife. Querol "testified" and «deposed" that the lieutenant had "carried off the wife of the said Bernat from their house into his personal quarters». The crown's other witness, however, testified «that the said wife of the said Bernat Querol went out of the house of Bernard through a window and afterwards went down through the terrace» to the house of Andreu d'En Adjaz «where the merchants stayed». There she had hidden herself: "at her insistence, she was closed up in a trunk [or box] there by one of the said merchants». The substance of the notary's complaint or perhaps plot against the royal official is clear, though the wife's actions are obscured by the vocabulary employed. "Consequently, both because of the [previous] false testimony he gave, and also because he does not respond to questions connected with the counsel he gave about the aforesaid false testimony" on the 
marriage, the king condemned Querol to a fine of fifty pounds (a thousand sous) in Barcelona money.

Here the pardon came into play. The king especially decreed that Querol, «by reason of this condemnation, not become infamous", since "from the fullness of our power we lift from him all infamy for the aforesaid». More important, «he can licitly conduct the office of notary just as he was accustomed» to do before. King Jaume delivered this combination review, sentence, and pardon «in the cloister» of the Perpignan Dominicans on July 3 , with a list of magnates signing as witnesses. The relaxation of penalty is called here «a gift», perhaps indicating the intervention of a powerful patron. Unless perjury was involved in the crown lieutenant's defense, this had been a dastardly and potentially very damaging plot. While pardoning the notary from official disgrace or infamy, with its loss of certain public rights, and restoring him fully to his lucrative and honored profession, King Jaume also took care to put on record the trial, conviction, and fine. This was no peccadillo to be waived without further detail, but a public scandal to be simultaneously brought to light and laid to rest? .

The fine, though severe, was not harsh for a case of such scandal. Is there a possibility here that the crown lieutenant has covered his own guilty tracks in the matter of adultery (with the con-

${ }^{7}$ Reg. 19, fol. 155r, v (3 July 1274) in appendix below, doc. III. Miret lists the document but adds "domus» to its dateline and inverts the «pluribus aliis" witnesses. "Carol» is a dialect variant of Querol, and might perhaps be kept in our discussion. «Terratan, though related to Latin terratum, echoes here Catalan terrada, a sizable platform or terrace, rather than «a field» as Ducange finds in earlier usage. "Caxia» is a regional variant of Latin caxa, capsa, and does not seem related to Catalan catxar in its rare meaning of «hide». I am unsure of my transcription and identification of the surname En Adjarz. For Alfonso, see his Siete partidas, part III, tit. 16, ley 42, and tit. 19, ley 16; on Alfonso's «gift» as motive for a pardon, see above, note 2 and text. Manuel Dualde Serrano ed., Fori antiqui Valentiae (Valencia 1967), III, no. 7, XXII, no. 6. The august witnesses in our document III translate from the Latin as Guerau the viscount of Cabrera, Galceran d'Urg, Guillem de Castellnou, Dalmau de Castellnou, Ramon de Cabrera, and the crown vicar for Cerdanya Ramon Fort de Bellpuig. 
nivance of the equally guilty wife) and compromised the veracity of the notary in this domestic matter by revealing the sharp practice in the previous marriage case, joining the two cases then in common hearings? In this connection, it is worth noting that King Jaume had delivered a sentence just four days previously in this same cloister and with the same eminent signatories, exonerating another official, the crown bailiff of Perpignan, in an even more flagrant scandal. A group of citizens had accused the bailiff of closing off with armed men the street and house of Astruga, wife of the butcher Pere Cornel, and climbing by ladder into the house to rape her, having first sent her husband off to by cattle. They charged him also with pursuing the wife of Pere de Millans, of holding a women of Fiter and her husband prisoner and raping her, and of deflowering a woman official of a hospital. King Jaume had noted that conviction would have neccesitated the death penalty; but with the witness contradicting each other and Astruga actually defending her supposed lover, the king had to find charges unproven and the accused official innocent. Our own second scandal, hard on the heels of that uproar, may well have seemed worth a pardon or even a cover-up ${ }^{8}$. The fourth case is another crime of passion, complicated by bloody violence. Its charter is a waiver of persecution for an obviously guilty recipient. Given at Barcelona on July 30 , it waived charges and liabilities both civil and criminal against the persons and properties of a family in the Cerdagne region. The culprit was Ramon Valent, the accomplices his brother Bernat and Bernat's son Pere. Bernat, to whom the document was personally directed, came from Enveig, now in the French Cerdagne in the Pyrenees. The criminal blow, wounding their fellow resident Jaume de Soldevila, «a cleric of Arbúcies», today in Spanish Cerdanya, was delivered not by Bernat but by his brother Ramon. The victim by now "was healed", and the episode therefore long past. After a sweeping waiver, not reserving even the usual obligation to answer any civil suits later

${ }^{8}$ Huici, Colección diplomática, III, part 2, doc. 1468 (3 July 1274), from register 20, fol. 291. 
arising from plaintiffs other than public authority, the king offers clarifying details of the case. «We grant you this release, because we understand that the said Jaume abducted [perhaps «raped»] a daughter of the said Bernat Valent, and carried her off, and was holding her at the time of the said wound inflicted on him». Bernat would have been the instigator of this rescue attempt, explaining his centrality in the pardon.

Nothing is said of the girl, or of the crime of kidnapping any woman, one of the most serious delicts in local law, and a crime formally as well against the relatives and the ruler himself. Roman Law, whose principles dominated the king's cases, did distinguish between abduction and sexual violation; but even abduction of a woman meant death plus confiscation of all property for the malefactor, unless voluntary marriage then took place. This Jaume, as a cleric, may have involved the church courts and canon law in the case, thus inviting the crown's attention and resolution of complexities. Nothing is said of that other jurisdiction, however, and the situation may have been more straightforward. If Jaume were a lower cleric and therefore not bound to celibacy, he may have made the victim his wife; in that situation, all parties were now formally laying to rest the episode and its mutual crimes on both sides. Is there a hint, in that case, of the primitive custom of ritually bearing away one's intended bride, perhaps a factor mitigating guilt in that isolated mountaion community?

Kidnapping and carrying of a woman to marry her was not uncommon even in the king's Catalan capital. In 1244 James and his court had ordered Barcelona to insert permanently into "your book of customs» a special "constitution» against the practice, «since many reckless men at Barcelona and elsewhere in Our land carry off maidens and daughters of men of standing, so that by seducing them they might join with them in marriage». To end this "seduction» activity, the king ordered such men exiled for life, even though they had clandestinely married the women. Women apparently cooperated in this custom of elopement, so the law also disinherited any daughter «who shall take a man or shall permit herself to be carried off without matri- 
mony or shall flee with any man voluntarily", without the express consent of parent or guardian'.

The fifth case was handled back in Barcelona in mid-August, but illustrates in fact the reissue of an important pardon already presented long before. It serves to caution us that the incidents seemingly recent or recently noticed in some pardons may really have had a previous history. It concerns "the brawl» between the Plegamans family (Berenguer, Bonanat, Guillem, and Romeu) assisted by Jaume Ferrer, and the Saletes brothers (Guillem and Ferrer), in which Berenguer and Guillem de Plegamans and Jaume Ferrer had been killed. No details are given, so this may have been an ongoing feud or strife, and it may have involved the gangs of retainers such families boasted. The Plegamans were a patrician clan more prominent in public affairs than were even the high nobles, furnishing the king with confidantes, admirals, ambassadors, bailiffs and other functionaries. The notable representatives of the family in this century were Ramon (died 1240), crown lieutenant for Catalonia and quartermaster-general for the conquest of Majorca, and his grandson Romeu, crown vicar of Barcelona. The Saletes or Salates family (both spellings appear in the document) were far less distinguished. Bonanat and Romeu survived the massacre, to plead self-defense «in the court of Guillem Durfort our vicar of Barcelona in our place». Backed by «acceptable witnesses», they won at least this waiver of all future prosecution and civil or criminal penalty against themselves or their properties. The common proviso was added, that they must answer any civil suit brought against them by Guillem and Ferrer Saletes «in connection with the aforesaid death(s)", an unlikely eventuality because all the casualties had been on the Plegamans side.

A peculiarity of this whole tale is that the same two survivors had presented themselves before the king at Valencia city almost

${ }^{9}$ Reg. 19, fol. 15Iv (30 July 1274) in appendix below, doc. IV (30 July 1274). On abduction and/or rape, see Alfonso X, Siete partidas, part. VII, tit. 20 , leyes 1,2 . The statute is in Documentos de Jaime I de Aragón, ed. Ambrosio Huici and M.D. Cabanes Pecourt, 4 vols. to date (Valencia 1976 ff.), II, 180, doc. 392 (14 August 1244). 
seven months previously, on February 4, to receive a similar pardon. That first charter had not included the death of Guillem Plegamans, or mentioned the witnesses proving self-defence, or described any hearing before Durfort. That first charter had been registered in this same codex, a hundred folios earlier, and had awarded all the privileges reproduced again now in this second version. A mere confirmation, so soon on the heels of the Valencian hearing, seems unlikely. Apparently the Plegamans family had desired vindication and protection more formally on their political homegrounds of Barcelona, especially if the original brawl had occurred in the far frontier region of conquered Valencia. Again we find a pardon (at least the second pardon) issuing from a formal trial or hearing, and from a verdict of innocent. Again we discover family, legal, and public details about Catalan society ${ }^{10}$.

Other cases from this same year and register reveal further variations in the purpose and procedure of such pardons. They also widen the social context to include mercantile offenses and such oddities as a kind of regional uprising which issued in mass pardons. Considerations of space exclude them here. I shall analyze these other cases in a separate article. This introductory study meanwhile can serve to alert historians to a category or typology of social history both important and neglected for the realms of Aragon.

${ }^{10}$ ACA, Reg. Canc. 19, fol. 157v (15 August 1274) in appendix below, doc. V; cf. fol. 60 (4 February 1273, an incarnational dating equivalent to 1274). The Romeu Plegamans here may have been the famous grandson of the great Ramon, or only another of the extended clan bearing that family pre-name. 


\section{APPENDIX}

In these transcriptions I follow the Madrid Normas, with minor adjustments. Signs include: ${ }^{\circ}[\mathrm{b}$ for holes, requiring conjectural additions; / to set off words inserted above the line; $<>>$ to enclose deteriorated or partially reconstructed text; and [ ] for editorial intrusion. I distinguish $\mathrm{u}$ and $\mathrm{v}$, but not $\mathrm{i}$ and $\mathrm{j}$.

ACA, Reg. Canc. 19, fol. 133

Perpignan

13 June 1274

Nos Iacobus dei gracia etc. absolvimus et difinimus ac remittimus de speciali gracia tibi Thome Fabri, Bernardo Antonii clerico, Arnaldo Pauci, Guillelmo Guayta, Astrugue Arufade, et Bernardo Dominici, et Eldiardi Galline, Bernardo de Baioles, Fratri Gueraldo hospitalario de Salsis, Bernardo Sancii, et Ermen[n]gurdi filio Iohannis Pagesii quondam, et vestris omnem peticionem et demandam quan racionem [= racione] mortis Berengarii de Minorissa, de qua Berengarius de $\mathrm{Na}$ Flors inculpatus fuit, habebamus et habere seu movere poteramus contra vos seu contra ter[r]as et domos ac vineas et alias possessiones que fuerunt dicti Berengarii de Na Flors quondam, quas vos quocumque titulo habetis et possidetis.

Ita videlicet quod racione predicta non possimus contra vos seu contra dictas terras, domos, vineas, et alias possessiones predictas movere vel facere peticionem aliquam seu demandam; set habeatis ipsas ad vestros voluntates, salvo alio iure nostro si quid in ipsis habemus.

Mandantes firmiter baiulis, vicariis et universis aliis officialibus et supditis nostris presentibus et futuris, et [sic] quod predicta firma habeant et observent, et non contraveniant nec aliquem contravenire permittant aliqua racione.

Datum Perpiniani, XVI kalendas Iulii, anno domini MCCLXX quarto.

\section{II}

A.C.A., Reg. Canc. 19, fol. 139v.

Perpignan

26 June 1274

Iacobus dei gracia rex Aragonum etc. Incelato quod cum tu Guillemeta et Guillema mater tua inculpate simul cum aliis de morte Iohannis de Fraix quondam, ita videlicet quod tu et dicta mater tua consenseratis eidem morti, cum invenerimus te nec dictam matrem tuam culpabiles non fuisse mortis predicte et quod illi qui ipsam mortem perpetrarunt composuerunt super ipsam mortem cum parientibus dicti 
mortui et intrant secure in Montepessulano: idcirco per nos et nostros absolvimus et difinimus ac remittimus vobis Guillemete et matri tue predicte omnem peticionem et demandam ac penam civiles et criminales quas contra personam tuam vel dicte matris tue aut contra res tuas seu suas habebamus, et habere, imponere, seu infligere poteramus sive possemus racione mortis predicte.

Concedentes tibi et matri tue quod possitis redire et stare in Montepessulano salve et secure et sine metu alicuius pena $[\approx$ pene], sup $[=$ sub] nostri guidatico et comenda. Mandantes etc.

Datum Perpiniani, VIII kalendas Iulii, anno domini MCCLXX quarto.

\section{III}

ACA, Reg. Canc. 19, fol. 155 r, v

Perpignan

3 July 1274

Iacobus dei gracia etc. Fuissent [sic] denunciatum quod Bernardus Karoli scriptor publicus Perpiniani consuluit Guillelme Mola de Telosa quod produceret in testem Guillelmum Sanxo et inde duceret eum ut ferret falsum testimonium pro ipsa super facto matrimonii ipsius Guillelme et Guillelmi de Valespiro.

Nos quod [= quando?] super predictis testes recipi fecerimus, invenerimus per testimonium dicte Guillelme predictus Bernardus Karoli consuluit sibi ut produceret in testem dictum Guillelmum Sanxo et consuleret ei quod ferret falsum testimonium.

Et dictus Guillemus Sanxo confessus fuerit in testimonio suo quod tulit falsum testimonium in dicto facto, concilio dicte mulieris.

Et invenerimus eciam, in testimonio dicti Bernardi Karoli quod fecit super facto Bartholomei de Manibus et uxoris sue, ipsum Bernardum deposuisse quod Bartholomeus de Manibus extraxit uxorem ipsius Bernardi de domo sua sub gremio suo; et per alios testes invenerimus quod dicta uxor Supra dicti/Bernardi Karoli exivit de domo ipsius Bernardi per quandam fenestram et postea descendit per terradam in domui [sic] Andree den Adjarz ubi morabantur mercatores. Et fuit inclusa ad suam instanciam in quadam caxia ibidem per alterum dictorum mercatorum.

Et sic per predictam appereat < dictum Bernardum Karoli seipsum > deposuisse in dicto testimonio suo.

Idcirco tum propter falsum testimonium < quod fecit, tum eciam quia non respondeat questionibus $>$ racione co[n]sulii quod dedit super predicto falso testimonio faciendo a dicto Guillelmo racione falsi testimonii quod fecit, eundem Bernardum in L libris Barchinone condempnamus.

Volumus tamen < facere graciam quod propter > huiusmodi condempnacionem non fiat infamis; immo possit officium notarie sicut 
consuevit [fol. $155 \mathrm{v}]$ licite exercere. Nos enim ipsum de plenitudine potestatis nostre relevamus ab omni infam[i]a predictorum.

Lata sentencia in claustro Fratrum Predicatorum Perpiniani quinto nonas Iulii, anno domini MCCLXX quarto, presentibus Gueraldo vicecomite Capraria, Guillelmo vicecomite Capraria, Castri Novi, Gaucerando de Urgio, Raimundo Fortis de Bellopodio, Raimundo de Capraria, et Dalmacio de Castro Novo, et pluribus aliis.

\section{IV}

ACA., Reg. Canc. 19, fol. 151v

Barcelona

30 July 1274

Noverint universi quod nos lacobus dei gracia etc. per nos et nostros remittimus, absolvimus et deffinimus tibi Bernardo Valent de Enveja et Petro filio tuo et Raimundo Valent fratri tuo et vestris in perpetuum omnem peticionem, questionem, et demandam quam vobis facere possumus, et omnem penam civilem et criminalem quan super vos vel bona vestra possumus infelligere [ = inflicgere] vel imponere, occasione vulneris per dictum Raimundum illati Iacobo de Soldevila, clerico de Arbuçio, de quo quidem cuaratus est.

Ita scilicet quod racione dicti vulneris non possumus nos vel nostri vobis vel vestris peticionem aliquam facere vel movere; set sitis inde quantum ad nos quitii et penitus absoluti, prout melius dici potest et intelligi ad vestrum vestrorumque bonum et sincerum intellectum.

Predictam itaque soluccionem tibi facimus eo quia intelleximus quod dictus Iacobus rapuit quandam filiam tui dicti Bernardi Valent, et secum duxit, ac ipsam tenebat tempore dicti vulneris sibi illati.

Mandantes vicariis, et aliis officialibus et subditis nostris presentibus et futuris quod dictam remissionem et absolucionem et absolucionem et diffinicionem nostram firmam habeant et observent, et non in aliquo contraveniant nec in [sic] aliquem contravenire permittant aliqua racione.

Datum Barchinone, III kalendas Augusti, anno domini MCCLXX quarto.

ACA, Reg. Canc. 19, fol. 157v

Barcelona

15 August 1274

Noverint universi quod nos Iacobus dei gracia rex Aragonum, Maioricarum, et Valencie, comes Barchinone et Urgelli, et dominus Montispessulani intelleximus quod in rixa, que fuit inter Berengarium de Plicamanibus et Guillelmum de Plicamanibus et Iacobum Ferrarii ex $1^{\text {a }}$ parte et Guillelmum Salates et Ferrarium Salates fratres ex altera 
(in qua quidem mortui fuerunt omnes ipsi predicti), Romeus de Plicamanibus et Bonanatus de Plicamanibus fratres qui supervenerunt rixe fecerunt in eorum defensionem quicquid fecerunt in eandam [sic]; et hoc probaverint per testes idoneos in posse Guillelmi Durfortis vicarii nostri Barchinone loco nostri.

Idcirco per nos et nostros absolvimus et diffinimus predictos Romeum et Bonanatum fratribus [sic] et sius in perpetuum omnem questionem, peticionem et demandam et omnem penam civilem vel criminalem, quam contra eos vel bona eorum possemus facere vel movere occasione mortis predicte. Ita scilicet [quod] non possimus eisdem occasione dicte mortis peticionem aliquam facere vel demandam; et sint inde cum omnibus bonis eorum habitis et habendis quitii et penitus perpetuo absoluti, prout dici potest etc., ipsis tamen facientibus dictis Guillelmo Saletes et Ferrario Salestes conquerentibus de ipsis racione mortis predicte iusticie complementum. Mandantes etc.

Datum Barchinone, XVIII kalendas Septembris, anno domini MCCLXX quarto. 